\title{
Non-pathogenic microflora of a spring water with regenerative properties
}

\author{
GIOVANNI NICOLETTI ${ }^{1-3}$, MARTA CORBELLA ${ }^{4}$, OMAR JABER ${ }^{1-3}$, \\ PIERO MARONE ${ }^{4}$, DANIELE SCEVOLA ${ }^{4,5}$ and ANGELA FAGA ${ }^{1-3}$
}

\begin{abstract}
${ }^{1}$ Plastic and Reconstructive Surgery, Department of Clinical Surgical Diagnostic and Pediatric Sciences, University of Pavia;
${ }^{2}$ Plastic and Reconstructive Surgery Unit, Salvatore Maugeri Research and Care Institute; ${ }^{3}$ Advanced Technologies for Regenerative Medicine and Inductive Surgery Research Centre, University of Pavia; ${ }^{4}$ Department of Infectious Diseases, San Matteo Research and Care Institute; ${ }^{5}$ Department of Internal Medicine and Medical Therapeutics, University of Pavia, I-27100 Pavia, Italy
\end{abstract}

Received June 12, 2015; Accepted July 24, 2015

DOI: $10.3892 /$ br.2015.507

\begin{abstract}
The Comano spring water (Comano, Italy) has been demonstrated to improve skin regeneration, not only by increasing keratinocyte proliferation and migration, but also by modulating the regenerated collagen and elastic fibers in the dermis. However, such biological properties may not be entirely explained by its mineral composition only. As the non-pathogenic bacterial populations have demonstrated an active role in different biological processes, the potential presence of non-pathogenic bacterial species within the Comano spring water was investigated in order to identify any possible correlation between these bacterial populations and the demonstrated biological properties of this water. The water was collected at the spring using an aseptic procedure and multiple cultures were carried out. A total of 9 different strains were isolated, which were Aeromonas hydrophila, Brevundimonas vesicularis, Chromobacterium violaceum, Citrobacter youngae, Empedobacter brevis, Pantoea agglomerans, Pseudomonas putida, Pseudomonas stutzeri and Streptococcus mitis. All the isolated bacterial strains, although showing a rare potential virulence, demonstrated peculiar and favorable metabolic attitudes in controlling environmental pollution. The therapeutical effects of certain spring waters are currently being proven as correlated not only to their peculiar mineral composition, but also to the complex activity of their resident non-pathogenic bacterial populations. Although the present study provided only preliminary data, some of the non-pathogenic bacterial populations that were identified in the Comano spring water are likely to produce molecular mediators with a role in the wound
\end{abstract}

Correspondence to: Professor Giovanni Nicoletti, Plastic and Reconstructive Surgery, Department of Clinical Surgical Diagnostic and Paediatric Sciences, University of Pavia, 74 Viale Brambilla, I-27100 Pavia, Italy

E-mail: giovanni.nicoletti@unipv.it

Key words: spring water, Comano spring water, skin regeneration, microbiota, non-pathogenic bacterial species healing process that, thus far, remain unknown. Numerous other unknown bacterial species, comprehensively termed DNA-rich 'dark matter', are likely to contribute to the Comano water regenerative properties as well. Therefore, the non-pathogenic bacterial populations of the Comano spring water are possibly credited for its demonstrated regenerative properties.

\section{Introduction}

The benefits of spring waters in the treatment of actual pathologies and/or in re-establishing the physiological wellness of different organs and systems have been demonstrated since the most ancient times, and specific indications have been historically attributed to each spring.

However, the molecular mechanisms and the various interactions responsible for the anti-inflammatory and regenerative properties of spring waters remain largely unknown and require investigation.

Our previous study demonstrated that an Italian spring water (Comano-Trentino) can improve skin regeneration in an animal experimental model, not only by increasing keratinocyte proliferation and migration, but also by modulating the regenerated collagen and elastic fibers in the dermis (1).

However, such biological properties may not be entirely explained by the mineral composition only.

As the non-pathogenic bacterial populations have demonstrated an active role in different biological processes, the potential presence of non-pathogenic bacterial species within the Comano spring water have been investigated in order to identify any possible correlation between these bacterial populations and the demonstrated biological properties of this water.

\section{Materials and methods}

General. The Comano spring water was collected at the spring with an aseptic procedure (Fig. 1) in January, June and October 2014. A single operator wearing sterile surgical gloves collected $3,000 \mathrm{ml}$ of water each time with a sterile 50-ml syringe. The samples were poured into 3 sterile one-liter containers for microbiological analysis and stored at $4^{\circ} \mathrm{C}$. 
Sample processing, isolation and identification of bacteria. Samples were transported to the Laboratory of Bacteriology, Microbiology and Virology Department, San Matteo Hospital Foundation, Research and Care Institute (Pavia, Italy), at $4^{\circ} \mathrm{C}$ and processed rapidly following collection.

Two pairs of BD BACTEC ${ }^{\mathrm{TM}}$ culture aerobic/anaerobic vials were inoculated each with $10 \mathrm{ml}$ water. Subsequently, the samples were incubated in a BACTEC ${ }^{\mathrm{TM}} 9240$ automated blood culture system (BD Biosciences, Sparks, MD, USA), according to the manufacturer's instructions, for 7 days.

Six $0.20-\mu \mathrm{m}$ pore cellulose nitrate membranes (Nalgene 0.2 Analytical filter Unit; Thermo Fisher Scientific, Inc., Waltham, MA, USA) were used to filter $100 \mathrm{ml}$ of water each. Five membranes were subsequently placed on a different plating medium (blood, chocolate, McConkey, mannitol salt or Sabouraud dextrose agars) and incubated in aerobic conditions at $37^{\circ} \mathrm{C}$ for 3 days. One membrane was placed on Schaedler blood agar medium and incubated in anaerobic conditions at $37^{\circ} \mathrm{C}$ for 6 days.

Similarly, a 1,000-ml water sample was filtered through a $0.20-\mu \mathrm{m}$ pore cellulose nitrate membrane and processed according to the guidelines for Legionella detection in water (2). In particular, buffered charcoal yeast extract and glycine, vancomycin, polymyxin $\mathrm{B}$ and cycloheximide plates were inoculated and incubated at $37^{\circ} \mathrm{C}$ with $5 \% \mathrm{CO}_{2}$ for 14 days.

Isolated organisms were biochemically identified with API NE (BioMerieux SA, Marcy l'Etoile, France) or using the Phoenix 100 ${ }^{\mathrm{TM}}$ (BD Biosciences) automated system.

\section{Results}

Positive identification of cultures. BD BACTEC ${ }^{\mathrm{TM}}$ culture aerobic/anaerobic vials became positive after 3 days.

Biochemical identification of the bacterial cultures. The biochemical identification of the cultured bacteria provided different results at different times. The Phoenix $100^{\mathrm{TM}}$ (BD Biosciences) automated system identified Citrobacter youngae and Pantoea agglomerans in January 2014, Pseudomonas stutzeri and Streptococcus mitis in June 2014 and no colonies in October 2014. The microorganisms isolated with API NE (BioMerieux sa) were Aeromonas hydrophila (CB $6 \mathrm{UFC} / 100 \mathrm{ml})$, Chromobacterium violaceum (CB $2 \mathrm{UFC} / 100 \mathrm{ml}$ ) and Empedobacter brevis (CB 3 UFC/100 ml) in January 2014, Brevundimonas vesicularis (CB $7 \mathrm{UFC} / 100 \mathrm{ml}$ ) and Pseudomonas putida (CB 4 UFC/100 ml) in June 2014, and Aeromonas hydrophila (CB $3 \mathrm{UFC} / 100 \mathrm{ml}$ ) and Pseudomonas putida (CB 8 UFC/100 ml) in October 2014.

The isolates at different times per identification system are summarized in Table I. A classification of the isolates is provided in Table II.

\section{Discussion}

The Comano spring water is a hypotonic, bicarbonate-calcium-magnesium mineral water that is rich in fluoride, and has a neutral $\mathrm{pH}$ and a low-buffer capacity. The ECOOPERA S.C. laboratory (Gardolo, TN, Italy; ACCREDIA

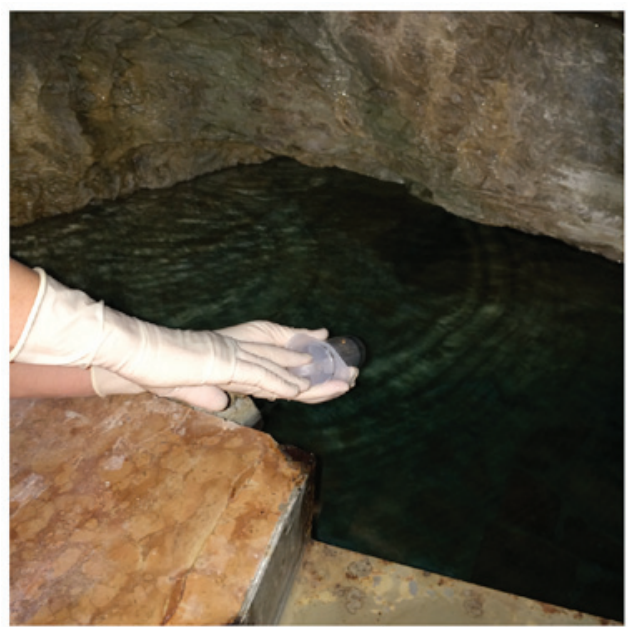

Figure 1. Water collection at the spring with aseptic procedure using sterile gloves and a sterile $50 \mathrm{ml}$ syringe.

certified no. 0252) regularly certifies this water as bacteriologically pure, the latter definition meaning that it does not contain pathogenic microorganisms nor microorganisms indicating fecal or other contamination (3).

A total of 9 different strains were isolated from the Comano spring water: Aeromonas hydrophila, Brevundimonas vesicularis, Chromobacterium violaceum, Citrobacter youngae, Empedobacter brevis, Pantoea agglomerans, Pseudomonas putida, Pseudomonas stutzeri and Streptococcus mitis.

Aeromonas hydrophila is the most prominent of the 6 species of Aeromonas (4). It is a heterotrophic Gram-negative bacterium mainly identified in areas with a warm climate. This bacterium can be found in fresh or brackish water and can survive in aerobic and anaerobic environments. Aeromonas hydrophila represents a constant component of the microbiota in fresh reservoirs where, together with other microorganisms, it acts as a natural biofilter and promotes water self-purification. It is present in normal microflora of hydrobionts inhabiting fresh reservoirs (5). Recently, Aeromonas hydrophila was isolated in samples from Moroccan Atlantic Ocean water (6), where antifungal and antibacterial activity was demonstrated.

Brevundimonas vesicularis is an environmental Gram-negative bacillum that has demonstrated the capacity to degrade sulfonated naphthalene-formaldehyde condensate compounds isolated from textile industry-activated sludge wastewater (7).

Chromobacterium violaceum is a facultative anaerobe Gram-negative bacterium, considered to be non-pathogenic for humans. This bacterium appears to control microbial infection and decrease the risks of resistance development (8). Violacein, the pigment of Chromobacterium violaceum, has potential medical applications as a drug with different properties: Antitrypanocidal, antileishmaniosis, antimycobacterial, antimalaric, anti-ulcerogenic, anticancer and antioxidant (9). Chromobacterium violaceum was also isolated in samples from Moroccan Atlantic Ocean water (6).

The Citrobacter youngae species are straight, facultative anaerobic Gram-negative bacilli that are commonly found in water, soil, food and in the intestinal tracts of animals and 
Table I. Isolates at different times per identification system.

Identification system

\begin{tabular}{|c|c|c|}
\hline \multirow[b]{2}{*}{ Dates } & \\
\hline & Phoenix $100^{\mathrm{TM}}$ & API NE \\
\hline January 2014 & $\begin{array}{l}\text { Citrobacter youngae } \\
\text { Pantoea agglomerans }\end{array}$ & $\begin{array}{l}\text { Aeromonas hydrophila }(\mathrm{CB} 6 \mathrm{UFC} / 100 \mathrm{ml}) \\
\text { Chromobacterium violaceum }(\mathrm{CB} 2 \mathrm{UFC} / 100 \mathrm{ml}) \\
\text { Empedobacter brevis }(\mathrm{CB} 3 \mathrm{UFC} / 100 \mathrm{ml})\end{array}$ \\
\hline June 2014 & $\begin{array}{l}\text { Pseudomonas stutzeri } \\
\text { Streptococcus mitis }\end{array}$ & $\begin{array}{l}\text { Brevundimonas vesicularis (CB } 7 \mathrm{UFC} / 100 \mathrm{ml}) \\
\text { Pseudomonas putida (CB } 4 \mathrm{UFC} / 100 \mathrm{ml})\end{array}$ \\
\hline October 2014 & Negative culture & $\begin{array}{l}\text { Aeromonas hydrophila (CB } 3 \mathrm{UFC} / 100 \mathrm{ml}) \\
\text { Pseudomonas putida (CB } 8 \mathrm{UFC} / 100 \mathrm{ml})\end{array}$ \\
\hline
\end{tabular}

Table II. Classification of isolates.

\begin{tabular}{llll}
\hline Isolates & \multicolumn{1}{c}{ Family } & Genus & Species \\
\hline Aeromonas hydrophila & Aeromonadaceae & Aeromonas & H.hydrophila \\
Brevundimonas vesicularis & Caulobacteriaceae & Brevundimonas & B. vesicularis \\
Chromobacterium violaceum & Neisseriaceae & Chromobacterium & C. violaceum \\
Citrobacter youngae & Enterobacteriaceae & Citrobacter & C. youngae \\
Empedobacter brevis & Flavobacteriaceae & Empedobacter & E. brevis \\
Pantoea agglomerans & Enterobacteriaceae & Pantoea & P. agglomerans \\
Pseudomonas putida & Pseudomonadaceae & Pseudomonas & P.putida \\
Pseudomonas stutzeri & Pseudomonadaceae & Pseudomonas & P. stutzeri \\
Streptococcus mitis & Streptococcaceae & Streptococcus & S.mitis
\end{tabular}

humans. Certain strains belonging to the genus Citrobacter have been reported to produce chitin/chitosan-like bioflocculants from acetate (10). Furthermore, degradation of the lipopolysaccharide of Citrobacter youngae releases polysaccharides with structure rarely identified in bacteria (11).

Empedobacter brevis, a Gram-negative aerobe also known as Flavobacterium breve, is the only member of the Empedobacter genus. It produces an enzyme that catalyzes the peptide-forming reaction producing l-alanyl-L-glutamine, a dipeptide of significant industrial interest by virtue of its widespread use in infusion therapy (12).

Pantoea agglomerans is a Gram-negative bacterium that belongs to the family Enterobacteriaceae. It is commonly isolated from plant surfaces, seeds, fruit (such as mandarin oranges) and animal or human feces. Pantoea agglomerans is primarily a plant epiphyte commonly found in diverse ecological niches, including aquatic environments, soil or sediments. Several strains of Pantoea agglomerans are sold as commercial biological control agents against the fire blight pathogen on apple and pear trees (13). The primary mode of action is competitive exclusion, which involves the occupation of sites otherwise colonized by the pathogens; however, according to the literature, certain strains may also contribute with the production of different antibiotic-like substances (herbicolins, pantocins, putative phenazine and other unknown compounds) (14). This bacterium was also isolated in samples from Moroccan Atlantic Ocean water (6).
Pseudomonas putida is a Gram-negative aerobic saprotrophic soil bacterium. As it is able to degrade organic solvents, such as toluene, and also convert styrene oil to biodegradable plastic polyhydroxyalkanoates, it may be used to degrade the polystyrene foam that was thought to be non-biodegradable (15). Furthermore, one of its engineered strains proved to be useful for in situ bioremediation of soils co-contaminated with organophosphorus and pyrethroid pesticides. In turn, Pseudomonas putida induces plant growth and protects the plants from pathogens. Therefore, researchers use it in bioengineering research to develop biopesticides and to the improve plant health (16).

Pseudomonas stutzeri, an almost universal Gram-negative ammonia-oxidizing bacterium, exhibits abilities in efficient heterotrophic nitrification and aerobic denitrification (17), and in organophosphorus pesticides degradation (18). Therefore, it is considered a suitable candidate to simultaneously remove nitrogen and phosphate in wastewater treatment. Similar to Brevundimonas vesicularis, it also demonstrated the capacity to degrade sulfonated naphthalene-formaldehyde condensate compounds isolated from textile industry-activated sludge wastewater (6).

Streptococcus mitis is a Gram-positive facultative anaerobe coccus that is an abundant human oral commensal and is reported as a potentially useful vector for mucosal vaccination (19).

While in the past microorganisms were recognized just as enemies of the human body, the trend has currently changed 
as the position of microbiota has recently undergone a turning point in the contemporary vision of medicine. Helminths, saprophytic mycobacteria, bifidobacteria and lactobacilli cause little, if any, harm and have been a part of human microecology for millenia. Deficient exposure to these may even explain the contemporary increase of immune disorders in a modern, highly sanitized society (20).

The use of probiotics, prebiotics, helminths or microbe-derived immunoregulatory substances has become a novel and valuable approach to disease prevention (20), and emerging clinical studies indicate that the supplementation and/or fecal microbial transplant (21) can improve bowel health and brain functions $(22,23)$.

The skin microbiota is constituted by bacteria and fungi with typical counts of $10^{2}-10^{7}$ cells $/ \mathrm{cm}^{2}$ in a diverse topography reflecting their different niches $(24,25)$.

Normal skin microorganisms are classified as either resident (i.e. adhering predominantly to the skin and annexes, maintaining viability and reproducibility) or transient (i.e. deposited but not adhering to the skin surface, with little nor sustained growth and reproduction). The skin ecosystem is a complex environment, extending to sub-epidermal compartments (26), tending to withstand pathogen colonization. Stability is maintained by interactions among different microbial species and the host. The topical use of probiotics has been reported to have a direct effect on the site of application, as natural defence mechanisms are induced by the competition with pathogens for nutrients, by the modulation of mucosal immune functions and by the production of antimicrobial metabolites (27-29).

Furthermore, epidermal keratinocytes have been demonstrated to produce antimicrobial peptides (30-32).

A correlation between the well-known beneficial effects on the skin and the resident non-pathogen bacterial populations was demonstrated in certain spring waters.

From the culture of Aquaphilus dolomiae, a non-spore forming bacterium belonging to the Neisseriaceae family isolated from Avène thermal Water (France), an organic substance, I-modulia, was obtained that is able to regulate keratinocyte inflammatory and lymphocyte immune responses (33-36).

Similarly $(37,38)$, the topical administration of a lysate of Vitreoscilla filiformis, a Gram-negative aerobic bacterium belonging to the Neisseriaceae family found in LaRoche-Posay thermal water (France), has been demonstrated to benefit the local skin immunity, possibly by the activation of cutaneous regulatory T cells $(39,40)$.

Our previous study on the properties of the Comano water on experimental fresh wounds in an animal model demonstrated a significant increase in the overall cell proliferation and a corresponding reduction of the local inflammatory response (1).

Such effects may not be entirely explained by the mineral composition only, but may be correlated to the antifungal and antimicrobial properties of some of the bacterial isolates as well (40).

Although showing a rare potential virulence (41-50), all the isolated bacterial strains demonstrate peculiar and favorable metabolic attitudes in controlling environmental pollution.

Skin regeneration is a complex process involving the close and coordinated interaction of different cell strains, as keratinocytes, fibroblasts and immune-system cells in the extracellular matrix environment.

The modulation of the wound proliferative process is likely to be influenced by the local microbiota as well, and this hypothesis has not been investigated previously. Therefore, it appears reasonable to conceive this study with the aim to provide a more comprehensive understanding of the regenerative properties of the Comano spring water.

Although the present study provided only preliminary data, some of the non-pathogenic bacterial populations that were identified in the Comano spring water are likely to produce molecular mediators with a role in the wound healing process that, thus far, remain unknown. Numerous other unknown bacterial species, comprehensively termed DNA-rich 'dark matter', are likely to contribute to the Comano water regenerative properties as well.

In conclusion, the therapeutical effects of certain spring waters are currently being proven as correlated not only to their peculiar mineral composition, but also to the complex activity of their resident, non-pathogenic bacterial populations (33-40).

Therefore, the non-pathogenic bacterial populations of the Comano spring water are likely to be credited for its demonstrated regenerative properties (1).

Such evidence may direct the introduction of novel research opportunities for regeneration to the role of microbiota.

\section{References}

1. Faga A, Nicoletti G, Gregotti C, Finotti V, Nitto A and Gioglio L: Effects of thermal water on skin regeneration. Int J Mol Med 29: 732-740, 2012.

2. International Organization for Standardization (ISO): Water quality-detection and enumeration of Legionella: Direct membrane filtration method for waters with low bacterial counts. ISO 11731-11732, 2004. http://www.legionellaonline.it/. Accessed May 26, 2015

3. Éditeur officiel du Québec: Regulation respecting bottled water: Food Products Act. http://www2.publicationsduquebec.gouv.qc. ca/dynamicSearch/telecharge.php? type=3\&file=/P_29/P29R2_A.HTM. Accessed August 1, 2015.

4. Horneman AJ and Ali A: Aeromonas. In: Manual of Clinical Microbiology. Versalovic J, Carroll KC, Funke G, Jorgensen JH, Landry ML and Warnock DW (eds). 10th edition. ASM Press, Washington, DC, pp658-665, 2011.

5. Kompanets EV, Isaeva NM and Balakhnin IA: Bacteria of the genus Aeromonas and their role in aquaculture. Mikrobiol $\mathrm{Zh} 54$ : 89-99, 1992 (In Russian).

6. El Amraoui B, El Amraoui M, Cohen N and Fassouane A: Antifungal and antibacterial activity of marine microorganisms. Ann Pharm Fr 72: 107-111, 2014.

7. Cheriaa J, Mosrati R, Ladhari N and Bakhrouf A: Acclimated biomass that degrades Sulfonated Naphthalene Formaldehyde Condensate. Pak J Biol Sci 11: 1588-1593, 2008.

8. Durán M, Faljoni-Alario A and Durán N: Chromobacterium violaceum and its important metabolites - review. Folia Microbiol (Praha) 55: 535-547, 2010.

9. Hoshino T: Violacein and related tryptophan metabolites produced by Chromobacterium violaceum: Biosynthetic mechanism and pathway for construction of violacein core. Appl Microbiol Biotechnol 91: 1463-1475, 2011.

10. Kimura K, Inoue $T$, Kato D, Negoro $S$, Ike $M$ and Takeo M: Distribution of chitin/chitosan-like bioflocculant-producing potential in the genus Citrobacter. Appl Microbiol Biotechnol 97: 9569-9577, 2013.

11. Kocharova NA, Mieszała M, Zatonsky GV, Staniszewska M, Shashkov AS, Gamian A and Knirel YA: Structure of the O-polysaccharide of Citrobacter youngae O1 containing an alpha-D-ribofuranosyl group. Carbohydr Res 339: 321-325, 2004.

12. Yokozeki $\mathrm{K}$ and Hara S: A novel and efficient enzymatic method for the production of peptides from unprotected starting materials. J Biotechnol 115: 211-220, 2005. 
13. Stockwell VO, Johnson KB, Sugar D and Loper JE: Antibiosis Contributes to Biological Control of Fire Blight by Pantoea agglomerans Strain Eh252 in Orchards. Phytopathology 92: 1202-1209, 2002.

14. Rezzonico F, Smits TH, Montesinos E, Frey JE and Duffy B: Genotypic comparison of Pantoea agglomerans plant and clinical strains. BMC Microbiol 9: 204, 2009.

15. Zuo Z, Gong T, Che Y, Liu R, Xu P, Jiang H, Qiao C, Song C and Yang C: Engineering Pseudomonas putida KT2440 for simultaneous degradation of organophosphates and pyrethroids and its application in bioremediation of soil. Biodegradation 26 223-233, 2015.

16. Espinosa-Urgel M, Salido A and Ramos JL: Genetic analysis of functions involved in adhesion of Pseudomonas putida to seeds. J Bacteriol 182: 2363-2369, 2000.

17. Li C, Yang J, Wang X, Wang E, Li B, He R and Yuan H: Removal of nitrogen by heterotrophic nitrification-aerobic denitrification of a phosphate accumulating bacterium Pseudomonas stutzeri YG-24. Bioresour Technol 182: 18-25, 2015.

18. Shi YH, Ren L, Jia Y and Yan YC: Genome Sequence of Organophosphorus Pesticide-Degrading Bacterium Pseudomonas stutzeri Strain YC-YH1. Genome Announc 3: e00192-15, 2015

19. Daifalla N, Cayabyab MJ, Xie E, Kim HB, Tzipori S, Stashenko P, Duncan M and Campos-Neto A: Commensal Streptococcus mitis is a unique vector for oral mucosal vaccination. Microbes Infect 17: 237-242, 2015.

20. Guarner F, Bourdet-Sicard R, Brandtzaeg P, Gill HS, McGuirk P, van Eden W, Versalovic J, Weinstock JV and Rook GA: Mechanisms of disease: The hygiene hypothesis revisited. Nat Clin Pract Gastroenterol Hepatol 3: 275-284, 2006.

21. Petrof EO, GloorGB, Vanner SJ, Weese SJ, CarterD, Daigneault MC, Brown EM, Schroeter K and Allen-Vercoe E: Stool substitute transplant therapy for the eradication of Clostridium difficile infection: 'RePOOPulating' the gut. Microbiome 1: 3, 2013.

22. Bested AC, Logan AC and Selhub EM: Intestinal microbiota, probiotics and mental health: From Metchnikoff to modern advances: Part III - convergence toward clinical trials. Gut Pathog 5: 4, 2013.

23. Selhub EM, Logan AC and Bested AC: Fermented foods, microbiota, and mental health: Ancient practice meets nutritional psychiatry. J Physiol Anthropol 33: 2, 2014

24. Grice EA and Segre JA: The skin microbiome. Nat Rev Microbiol 9: 244-253, 2011.

25. Huttenhower C, Gevers D, Knight R, et al; Human Microbiome Project Consortium: Structure, function and diversity of the healthy human microbiome. Nature 486: 207-214, 2012.

26. Nakatsuji T, Chiang HI, Jiang SB, Nagarajan H, Zengler K and Gallo RL: The microbiome extends to subepidermal compartments of normal skin. Nat Commun 4: 1431, 2013.

27. Krutmann J: Pre- and probiotics for human skin. Clin Plast Surg 39: 59-64, 2012.

28. Al-Ghazzewi FH and Tester RF: Impact of prebiotics and probiotics on skin health. Benef Microbes 5: 99-107, 2014.

29. Bockmühl D, Jassoy C, Nieveler S, Scholtyssek R, Wadle A and Waldmann-Laue M: Prebiotic Cosmetics: An Alternative to Antibacterial Products. Int J Cosmet Sci 29: 63-64, 2007.

30. Gallo RL, Murakami M, Ohtake T and Zaiou M: Biology and clinical relevance of naturally occurring antimicrobial peptides. J Allergy Clin Immunol 110: 823-831, 2002.

31. de Jongh GJ, Zeeuwen PL, Kucharekova M, Pfundt R, van der Valk PG, Blokx W, Dogan A, Hiemstra PS, van de Kerkhof PC and Schalkwijk J: High expression levels of keratinocyte antimicrobial proteins in psoriasis compared with atopic dermatitis. J Invest Dermatol 125: 1163-1173, 2005.

32. Faga A, Pelfini C, Concia E and Bona F: Variazioni della naturale attività antibatterica della cute: Un metodo di valutazione di detergenti e/o antisettici. Chron Derm 2: 233-241, 1981 (In Italian).

33. Nocera T, Fabre P, Rossi AB and Mengeaud V: Clinical development program of a new dermocosmetic range of products containing I-modulia (Aquaphilus dolomiae extract) in atopic dermatitis. J Am Acad Dermatol 70 (suppl 1): AB6, 2014.
34. Patrizi A, Bacquey A, Fabre P, Schmitt AM, Decoster CJ, Phulpin $\mathrm{C}$, Theunis $\mathrm{J}$ and Mengeaud V: Clinical and biometrologic evaluation of a novel emollient balm containing an Aquaphilus dolomiae extract in 1- to 4-year-old children suffering from atopic dermatitis: International, multicenter, randomized versus control group study. J Am Acad Dermatol 70 (suppl 1): AB62, 2014.

35. Aries MF, Fabre $P$, Vaissière $C$, Delga $H$, Leveque $M$, Castex-Rizzi N, Bessou-Touya S and Nguyen T: Antiinflammatory and immunomodulatory effect of I-modulia, an Aquaphilus dolomiae extract, on atopic dermatitis in vitro. J Am Acad Dermatol 70 (suppl 1): AB61, 2014

36. Aries MF, Fabre P, Duplan H, Hernandez Pigeon H, Galliano MF, Castex-Rizzi N, Bessou-Touya S and Nguyen T: I-modulia, an Aquaphilus dolomiae extract, stimulates innate immune response through Toll-like receptor activation. J Am Acad Dermatol 70 (suppl 1): AB63, 2014.

37. Mahe YF, Perez MJ, Tacheau C, Fanchon C, Martin R, Rousset F and Seite S: A new Vitreoscilla filiformis extract grown on spa water-enriched medium activates endogenous cutaneous antioxidant and antimicrobial defenses through a potential Toll-like receptor $2 /$ protein kinase C, zeta transduction pathway. Clin Cosmet Investig Dermatol 6: 191-196, 2013.

38. Gueniche A, Knaudt B, Schuck E, Volz T, Bastien P, Martin R, Röcken M, Breton L and Biedermann T: Effects of nonpathogenic gram-negative bacterium Vitreoscilla filiformis lysate on atopic dermatitis: A prospective, randomized, double-blind, placebo-controlled clinical study. Br J Dermatol 159: 1357-1363, 2008.

39. Volz T, Skabytska Y, Guenova E, Chen KM, Frick JS, Kirschning CJ, Kaesler S, Röcken $M$ and Biedermann T: Nonpathogenic bacteria alleviating atopic dermatitis inflammation induce IL-10-producing dendritic cells and regulatory Tr1 cells. J Invest Dermatol 134: 96-104, 2014.

40. Nakatsuji T and Gallo RL: Dermatological therapy by topical application of non-pathogenic bacteria. J Invest Dermatol 134: 11-14, 2014

41. Agger WA, McCormick JD and Gurwith MJ: Clinical and microbiological features of Aeromonas hydrophila-associated diarrhea. J Clin Microbiol 21: 909-913, 1985.

42. Minnaganti VR, Patel PJ, Iancu D, Schoch PE and Cunha BA: Necrotizing fasciitis caused by Aeromonas hydrophila. Heart Lung 29: 306-308, 2000.

43. Sneath PH, Whelan JP, Bhagwan Singh R and Edwards D: Fatal infection by Chromobacterium violaceum. Lancet 265: 276-277, 1953.

44. Janknecht P, Schneider CM and Ness T: Outbreak of Empedobacter brevis endophthalmitis after cataract extraction. Graefes Arch Clin Exp Ophthalmol 240: 291-295, 2002.

45. Jain S, Bohra I, Mahajan R, Jain S and Chugh TD: Pantoea agglomerans infection behaving like a tumor after plant thorn injury: An unusual presentation. Indian J Pathol Microbiol 55: 386-388, 2012

46. Shih CC, Chen YC, Chang SC, Luh KT and Hsieh WC Bacteremia due to Citrobacter species: Significance of primary intraabdominal infection. Clin Infect Dis 23: 543-549, 1996.

47. Shang ST, Chiu SK, Chan MC, Wang NC, Yang YS, Lin JC and Chang FY: Invasive Brevundimonas vesicularis bacteremia: Two case reports and review of the literature. J Microbiol Immunol Infect 45: 468-472, 2012

48. Von Graevenitz A and Weinstein J: Pathogenic significance of Pseudomonas fluorescens and Pseudomonas putida. Yale J Biol Med 44: 265-273, 1971

49. Noble RC and Overman SB: Pseudomonas stutzeri infection. A review of hospital isolates and a review of the literature. Diagn Microbiol Infect Dis 19: 51-56, 1994.

50. Mitchell J: Streptococcus mitis: Walking the line between commensalism and pathogenesis. Mol Oral Microbiol 26: 89-98, 2011. 